\title{
PEMILHAN UMUM SERENTAK DAPAT MEMPERKUAT SISTEM PRESIDENSIAL
}

\author{
Barhamudin \\ Fakultas Hukum Universitas Palembang \\ bsuryaigama@yahoo.com
}

\begin{abstract}
The purpose of this research is to find out whether general elections simultaneously have an influence on strengthening presidential systems. To find out the implications of simultaneous elections on elections in Indonesia. The research method in this study uses a normative juridical approach used to study or analyze secondary data in the form of legal materials, especially primary legal materials and secondary legal materials. Primary legal material is the 1945 Constitution of the Republic of Indonesia, Law Number 7 of 2017 concerning General Elections, Decision of the Constitutional Court Number 14 / PUU-XI / 2013 etc. Secondary legal materials are those that provide explanations and interpretations of sources of primary legal materials such as law books, legal journals, and others. Tertiary legal materials are legal materials that provide guidance or explanation of primary and secondary legal materials such as legal dictionaries, encyclopedias, and related documents. The results of the study were argued that the holding of elections simultaneously with the plurality system itself actually tended to produce few presidential candidates. When presidential elections the supporters of candidates in this system tend to ignore candidates who are not competitive (non-viable) so they can focus on the top two candidates. This encouraged a coalition process between parties from the start because there was only one election round. The party that should submit its own candidate but the candidate is less competitive tends to drop the candidate and endorse one of the two most competitive candidates. The plurality system, if implemented separately from the legislative elections, the parties in the legislative elections do not need to think about the influence of the presidential election. This plurality mechanism affects parties when carried out simultaneously with legislative elections. The parties tend to nominate one of the two most competitive candidates, and lead to gathering support for the legislative parties in the two candidates. When one of the candidates wins the presidential election, then support for the president in the legislature tends to be the majority or close to the majority. The combination of the presidential plurality election system carried out simultaneously with legislative elections is the most likely to help strengthen multi-party presidential systems. Thus the simultaneous implementation of elections will strengthen the presidential system in which the President and VicePresident are elected to gain strong legitimacy from the people, in order to realize the effectiveness of government and also the support base of the DPR.
\end{abstract}

Keywords: General voters; president and legislature; simultaneously.

\begin{abstract}
ABSTRAK
Tujuan peneitian ini untuk mengetahui apakah pemilihan umum secara serentak mempunyai pengaruh terhadap penguatan sistem presidensial.Untuk mengetahui implikasi pemilihan umum serentak terhadap pemilihan umum di Indonesia. Metode Penelitian dalam penelitian ini menggunakan pendekatan yuridis normatif digunakan untuk mengkaji atau menganalisis data skunder yang berupa bahan-bahan hukum, terutama bahan-bahan hukum primer dan bahan-bahan hukum sekunder. Bahan hukum primer adalah Undang-Undang Dasar Negara Republik Indonesia 1945, Undang-undang Nomor 7 Tahun 2017 tentang Pemilihan Umum, Putusan Mahkamah Konstitusi Nomor 14/PUU-XI/2013 dll. Bahan hukum sekunder adalah yang memberikan penjelasan dan tafsiran terhadap sumber bahan hukum primer seperti buku ilmu hukum, jurnal hukum, dan lain-lain. Bahan hukum tersier adalah bahan hukum yang memberikan petunjuk atau penjelasan bahan hukum primer dan sekunder seperti kamus hukum, ensiklopedia, dan dokumen yang terkait. Hasil penelitian diperoeh bahwa penyelenggaraan pemilu serentak dengan Sistem plurality sendiri sebetulnya cenderung menghasilkan sedikit kandidat presiden. Ketika pemilu presiden para pendukung kandidat dalam sistem ini cenderung mengabaikan para kandidat yang tidak kompetitif (non-viable) supaya mereka dapat fokus pada dua kandidat teratas. Hal ini mendorong proses koalisi antar partai sejak
\end{abstract}


awal karena hanya ada satu putaran pemilihan. Partai yang mestinya mengajukan calon sendiri namun calonnya kurang kompetitif cenderung akan mendrop calonnya dan mengendorse satu di antara dua calon paling kompetitif. Sistem plurality bila dilaksanakan terpisah dengan pemilu legislatif, maka partai-partai dalam pemilu legislatif belum perlu memikirkan pengaruh pemilu presiden tersebut. Mekanisme plurality ini berpengaruh terhadap partai-partai ketika dilaksanakan serentak dengan pemilu legislatif. Partai-partai cenderung akan mencalonkan salah satu dari dua kandidat paling kompetitif, dan berujung pada mengumpulnya dukungan partai-partai legislatif pada dua kandidat tersebut. Ketika salah satu dari kandidat itu memenangkan pemilu presiden, maka dukungan terhadap presiden tersebut di legislatif cenderung akan mayoritas atau mendekati mayoritas. Gabungan sistem pemilu presiden plurality yang dilaksanakan serentak dengan pemilu legislatif adalah yang paling mungkin membantu penguatan sistem presidensial multipartai. Dengan demikian penyelenggaraan pemilu serentak akan memkuat sistem presidensiil di mana Presiden dan Wakil Presiden terpilih memperoleh legitimasi yang kuat dari rakyat, dalam rangka mewujudkan efektivitas pemerintahan dan juga basis dukungan dari DPR.

Kata kunci : Pemiliha umum; presiden dan legislative; serentak.

\section{PENDAHULUAN}

\section{A. Latar Belakang}

Dalam sistim negara yang menganut demokrasi peralihan kekuasaan merupakan salah satu parameter demokratis tidaknya suatu negara melalui rekrutmen pejabat politik. Peralihan kekuasaan berarti bahwa kekuasaan atau jabatan politik tidak boleh dan tidak bisa dipegang terus-menerus oleh seseorang, seperti dalam sistem monarkhi. Artinya, kalau seseorang yang berkuasa terus-menerus atau satu partai politik mengendalikan roda pemerintahan secara dominan dari waktu kewaktu sistem itu kurang layak disebut demokratis. Dengan kata lain, demokrasi memberikan peluang peralihan kekuasaan atau pejabat politik secara teratur dan damai dari seorang Presiden kepada Presiden yang lain atau Kepala Daerah satu ke Kepala Daerah lain, dari satu partai politik ke partai politik yang lain. Dengan demikian, Demokrasi membuka peluang untuk mengadakan kompetisi karena semua orang atau kelompok mempunyai hak danalam meng peluang yang sama. Oleh karena itu dalam mengisi jabatan politik, sudah seharusnya peluang terbuka untuk semua orang yang memenuhi syarat, dengan kompetisi yang wajar sesuai dengan aturan yang telah disepakati. Dinegara-negara totaliter dan otoriter, rekruitmen politik hanyalah merupakan domain dari seseorang atau sekelompok orang kecil.

Semua Undang-Undang Dasar negara demokrasi, selalu mencantumkan dan menghendaki adanya pergantian kepemimpinan secara teratur melalui pemilu, oleh karena itu pemilu memiliki posisi strategis yang tidak dapat dilepaskan dari kebutuhan masyarakat akan demokrasi yang Setiap lima tahun sekali, proses berdemokrasi dijalankan masyarakat Indonesia untuk memilih pemimpin yang akan memperjuangkan kepentingan mereka di pentas politik. Kesadaran itu menuntut masyarakat untuk menetapkan pilihannya atas berbagai varian calon wakilnya yang sudah diseleksi partai politik sebagai lembaga resmi negara dalam menjalankan aktivitas politik secara legal. Pilihan yang ada menjadi sebuah pertaruhan penting dalam perjalanan Indonesia selama lima tahun mendatang.

$$
\text { Pemilu yang berfungsi }
$$

sebagai sirkulasi pergantian pemimpin diyakini sampai sekarang dapat memperlancar proses demokrasi di Indonesia. Pergantian 
kepemimpinan merupakan sebuah ritual wajib bagi sebuah negara dalam rangka usaha menciptakan kondisi pemerintahan yang dinamis, stabil secara sosial-politik dan memiliki sistem pembagian kerja yang jelas antara pemimpin dan pengikut. Bagaimanapun pemimpin harus selalu mengalami pergantian sebagai bukti regenerasi dalam sebuah pemerintahan berjalan baik. Dapat dikatakan, jika proses konsolidasi demokrasi melalui pemilu berlangsung secara luber (langsung, umum, bebas dan rahasia) dan jurdil (jujur dan adil), maka peluang demokrasi Indonesia untuk semakin kokoh menjadi terbuka lebar. Jika berkaca catatan sejarah, sejak pertama kali mendeklarasikan diri sebagai sebuah negara, Indonesia pertama kali menjalankan pemilu pada tahun 1955. Ketika itu, pemilu menghasilkan empat partai besar yang menguasai parlemen dan berhak menyandang amanah sebagai penyalur aspirasi rakyat Indonesia yang terbentang dari Sabang sampai Merauke. Seiring perjalanan waktu, pemilu semakin berkembang baik jumlah partai, aturan main dan beragam atribut lainnya. Perjalanan pemilu di Indonesia pun berkali-kali mengalami perbaikan sesuai kebutuhan zamannya dan kepentingan politik yang mengiringinya.

$\begin{array}{rrr}\text { Para pemegang jabatan } \\ \text { rakyat } & \text { harus } & \text { dapat }\end{array}$ mempertanggungjawabkan kepada rakyat apa yang dilakukan baik sebagai pribadi maupun sebagai pejabat politik. Seorang pejabat politik lainnya harus dapat menjelaskan kepada rakyat mengapa mimilih kebijakan A, bukan kebijakan B, mengapa menaikkan pajak dari pada melakukan efesiensi dalam pemerintahan dan melakukan pemberantasan KKN. Apa yang mereka lakukan terbuka untuk dipertanyakan kepada rakyat.

Sri Soemantri memaknai sistem pemerintahan berkenaan dengan sistem hubungan eksekutif dan legislatif. Ada dan tidak adanya hubungan antara eksekutif dan legislatif melahirkan adanya sistem pemerintahan parlementer dan sistem pemerintahan presidensial, yang dalam bahasa inggris disebut cabinet government system dan presidential government system atau the fixed executive system. ${ }^{1}$

Dalam perkembangan negara modern, penyelenggaraan kekuasaan negara didasarkan pada konstitusi. Konstitusi dapat berupa hukum dasar tertulis atau yang lazimnya disebut Undang-Undang Dasar. Melalui Undang-Undang Dasar kita dapat melihat negara mulai dari bentuk negara, bentuk pemerintahan, sistem pemerintahan dan jaminan hak asasi manusia.

Dalam konteks Indonesia, konstitusi tertulis tertuang dalam Undang-Undang Dasar 1945 (UUD 1945) yang telah mengalami perubahan menjadi Undang-Undang Dasar Negara Republik Indonesia 1945 (selanjutnya disebut UUD NRI 1945). Di dalamya memuat mengenai bentuk negara dan bentuk pemerintahan (Pasal 1 ayat (1) UUD NRI 1945) serta sistem pemerintahan. Sejak dahulu dikatakan bahwa UUD 1945 menganut sistem presidensial, sekurang-kurangnya sistem itulah yang semula dibayangkan ideal oleh kalangan perancang UndangUndang Dasar 1945. Ciri-ciri

\footnotetext{
${ }^{1}$ Titik Triwulan Tutik, Konstruksi Hukum Tata Negara Indonesia Pasca Amandemen UUD 1945, Jakarta: Kencana, 2011, Cet. Kedua, hal. 148.
} 
penting yang ada di sistem presidensial yakni : ${ }^{2}$

1. Presiden melaksanakan fungsi kepala negara dan kepala pemerintahan;

2. Presiden dipilih secara langsung oleh rakyat, oleh karenanya presiden bertanggungjawab kepada rakyat;

3. Presiden tidak tunduk kepada parlemen dan sebaliknya presiden tidak dapat membubarkan parlemen;

4. Presiden memiliki masa jabatan tetap;

5. Presiden memegang tanggungjawab pemerintahan. Akan tetapi, sistem presidensial yang dianut UUD 1945 sebelum amandemen tidak murni, karena Presiden dalam menjalankan pemerintahannya harus mempertanggungjawabkannya

kepada MPR sebagai lembaga parlemen yang mempunyai kedudukan sebagai lembaga tertinggi negara.

MPR juga berwenang memberhentikan Presiden ditengah masa jabatannya karena tuduhan pelanggaran haluan negara. Oleh karena itu salah satu di antara kesepakatan Badan Pekerja Majelis Permusyawaratan Rakyat saat melakukan pembahasan Perubahan UUD 1945 (1999-2002) adalah memperkuat sistem presidensial. Hal ini dibuktikan dengan dimuatnya ciri-ciri pokok sistem presidensial ke dalam Pasal 4 ayat (1), Pasal 6A ayat (1), Pasal 7, Pasal 7C UUD NRI 1945. Dengan demikian, jelaslah bahwa negara Indonesia di era reformasi ini menganut sistem presidensial. Karna ciri-ciri pokok

${ }^{2}$ Jimly Asshiddiqie, Format Kelembagaan Negara dan Pregeseran Kekuasaan Dalam UUD 1945, Yogyakarta: FH UII Press, 2005, Cet. Kedua, hal. 59-60. sistem presidensial disebutkan secara tegas dalam UUD NRI 1945. UUD NRI 1945 menempatkan presiden dalam posisi yang kuat dan strategis, karna presiden tidak dapat dijatuhkan selain dari alasan yang diatur secara limitatif oleh UUD NRI 1945 (Pasal 7A UUD NRI 1945).

Dalam hal pengisian jabatan Presiden, Pasal 6A ayat (2) menyebutkan bahwa "Pasangan Presiden dan Wakil Presiden diusulkan oleh partai politik atau gabungan partai politik peserta pemilihan umum sebelum pelaksanaan pemilihan umum". Pasal 6A ayat (5) UUD NRI 1945 menyatakan bahwa: "Tata cara pelaksanaan pemilihan Presiden dan wakil Presiden lebih lanjut diatur dalam undang-undang".

$$
\text { Berdasarkan ketentuan }
$$

tersebut maka lahirlah UndangUndang pelaksana Pemilihan Presiden dan Wakil Presiden, yakni Undang-Undang nomor 23 tahun 2003 yang sekarang telah dicabut dan diganti dengan Undang-Undang Nomor 42 tahun 2008 Tentang Pemilihan Umum Presiden dan Wakil Presiden yang menghendaki Pemilu Presiden dilaksanakan setelah pemilihan umum Anggota DPR, DPD dan DPRD (selanjutnya disebut Pemilu Legislatif). Terkait Undang-Undang Nomor 42 Tahun 2008, telah dilakukan permohonan Pengujian Undang-Undang oleh Effendi Gazali pada tanggal 10 januari 2013 kepada Mahkamah Konstitusi Republik Indonesia, yang pada intinya Mahkamah Konstitusi memutuskan bahwa model pelaksanaan Pemilu Presiden dan Wakil Presiden dengan Pemilu Anggota DPR, DPD dan DPRD untuk pemilihan umum seterusnya dilakukan secara serentak. Pemilu Presiden dan Wakil Presiden dengan 
Pemilu Anggota DPR, DPD dan DPRD dilaksanakan pada tahun 2019 dan berdasarkan UndangUndang Nomor 7 tahun 2017 Tentang Pemilihan Umum.

\section{B. Rumusan Masalah}

Berdasarkan uraian latar belakang tersebut, maka pokok permasalahan yang akan diteliti adalah : Apakah Pemilhan Umum serentak dapat memperkuat sistem presidensial yang dianut UUD NRI 1945?

\section{Tujuan Penelitian dan Manfaat Penelitian}

1. Tujuan Penelitian

Sesuai dengan permasalahan diatas, maka tujuan peneitian ini adalah:

a. Untuk mengetahui apakah pemilihan umum secara serentak mempunyai pengaruh terhadap penguatan sistem presidensial.

b. Untuk mengetahui implikasi pemilihan umum serentak terhadap pemilihan umum di Indonesia.

2. Manfaat Penelitian

a. Secara Teoritis

Penelitian ini dapat memperkaya khasanah ilmu pengetahuan dalam hukum tata negara khsususnya mengenai pemilu serentak terhadap penguatan sistem presidensial yang dianut oleh UUD NRI 1945.

b. Secara Praktis

Penelitian ini diharapkan dapat memberikan masukan bagi pembaca khususnya mengenai pengaruh pemilu serentak terhadap penguatan sistem presidensial yang dianut UUD NRI 1945.

\section{Metode Penelitian}

Penelitian ini menggunakan pendekatan yuridis normatif, Metode pendekatan yuridis normatif digunakan untuk mengkaji atau menganalisis data skunder yang berupa bahan-bahan hukum, terutama bahan-bahan hukum primer dan bahan-bahan hukum sekunder ${ }^{3}$.

Yaitu menganalisis bagaimana sistem pemerintahan yang ada di Indonesia menurut UUD 1945 pasca amandemen. Pendekatan yang dilakukan adalah pendekatan Undang-undang (statute approach) dengan menelaah semua undangundang dan regulasi yang bersangkut paut dengan isu hukum yang sedang ditangani, pendekatan ini akan membuka kesempatan bagi peneliti untuk mempelajari adakah konsistensi dan kesesuaian antara suatu undang-undang dengan undang-undang lainnya atau antara undang-undang dengan undangundang dasar atau antara regulasi dan undang-undang. ${ }^{4}$

Dalam proses pengumpulan bahan hukum, penulis menggunakan jenis data sumber hukum primer, sekunder dan tersier, yaitu:

a. Sumber hukum primer dalam hal ini adalah Undang-Undang Dasar Negara Republik Indonesia 1945, Undang-undang Nomor 7 Tahun 2017 Tentang Pemilihan Umum, Putusan Mahkamah Konstitusi Nomor 14/PUU-XI/2013 dll. dan juga peraturan-peraturan yang terkait dengan penelitian dalam ini.

b. Sumber hukum sekunder dalam hal ini adalah yang memberikan penjelasan dan tafsiran terhadap sumber bahan hukum primer seperti buku ilmu hukum, jurnal hukum, laporan hukum, media cetak atau elektronik, pendapat

3 Ronny Hanitijo Soemitro, 1988, Metodologi Penelitian Hukum dan Jurimetri, Ghalia Indonesia, hlm $11-12$.

4 Peter Mahmud Marzuki, 2008, Penelitian Hukum, Kencana Prenada Media Group, Jakarta, hlm 93. 
para sarjana, kasus-kasus hukum, serta simposium yang dilakukan pakar terkait dengan pembahasan $^{5}$ tentang sistem pemerintahan.

c. Bahan hukum tersier adalah bahan hukum yang memberikan petunjuk atau penjelasan bahan hukum primer dan sekunder seperti kamus hukum, ensiklopedia, dan dokumen yang terkait. $^{6}$

Pada penelitian yang digunakan adalah model studi pustaka (library research), yang dimaksud dengan studi kepustakaaan adalah pengkajian informasi tertulis mengenai hukum yang berasal dari Pelbagai sumber dan di publikasikan secara luas serta dibutuhkan dalam penelitian hukum normatif, 7 yakni penulisan yang didasarkan pada data-data yang dijadikan obyek penelitian, seperti peraturan perundangundangan, buku-buku pustaka, majalah, artikel, surat kabar, buletin tentang segala permasalahan yang sesuai dengan tesis ini yang akan di susun dan di kaji secara komprehensif.

Metode analisis yang digunakan adalah analisis kualitatif, yaitu metode analisis yang pada dasarnya mempergunakan pemikiran logis, analisis dengan logika, dengan induksi, analogi / interpretasi, komparasi dan sejenis itu. Metode berfikir yang dipergunakan adalah metode induktif, yaitu dari data / fakta

\footnotetext{
5 Jhonny Ibrahim, 2006, Teori dan Metodologi Penelitian Hukum Normatif, Bayumedia, Malang, hlm. 392.

${ }^{6}$ Ibid

7 Abdul Kadir Muhammad, 2004, Hukum Dan Penelitian Hukum, PT. Citra Aditya Bakti, Bandung, Hlm. 81.
}

menuju ke tingkat abstraksi yang lebih tinggi, termasuk juga melakukan sintesis dan mengembangkan teori (bila diperlukan dan datanya menunjang $)^{8}$. Dari analisis tersebut kemudian akan ditarik kesimpulan sebagai jawaban atas permasalahan yang ada.

\section{PEMBAHASAN}

Konsep birokrasi yang dipelopori Weber yang paling banyak dipakai dalam memahami birokrasi modern saat ini. Birokrasi sebagai organisasi memiliki rasionalitas dan pembagian kerja yang dilakukan secara khusus. Identitas yang mendasar dari birokrasi modern adalah adanya hirarki bersifat monokratik dan terbuka, adanya sistem pengaturan legal rasional yang diikuti oleh birokrat dan birokrat harus netral dari campur tangan politik. Birokrasi seharusnya memberikan pelayanan pada masyarakat secara efektif dan efesien. Birokrasi adalah alat pemerintah untuk mengatur masyarakat yang pelaksanaanya dilakukan oleh para birokrat. ${ }^{9}$ Kajian tentang birokrasi tidak dapat dilepaskan dari sumbangsih pemikiran Max Weber. Menurut Weber, birokrasi yang baik adalah bisa dilaksanakan dalam kondisi organisasi khusus sehingga dapat membedakan dengan organisasi lainnya. Birokrasi yang ideal ialah birokrasi murni atau paling rasional, terdapat sepuluh ciri dari tipe birokrasi ideal menurut Weber, yaitu:. ${ }^{10}$

1. Para anggota staf bersifat bebas secara pribadi yang

8 Sanapiah Faisal, 1990, Penelitian Kualitatif : Dasar-Dasar dan Aplikasi, YA 3, Malang, Hal.5

9 Hamka. Ketidaknetralan Birokrasi Indonesia. Jakarta: PT Elex Media Komputindo, 2014. Hal.14

${ }^{10}$ Delly Mustafa, Birokrasi Pemerintahan. Bandung: Penerbit AlfabetaMustafa, 2014, Hal. 18 
hanya menjalankan tugas impersonal sesuai jabatan;

2. Terdapat hirarki jabatan yang jelas;

3. Fungsi-fungsi jabatan diatur dan ditentukan secara tegas;

4. Para pejabat diangkat berdasarkan kontrak tertentu;

5. Para pejabat dipilih berdasarkan kualifikasi profesionalitas;

6. Para pejabat memiliki gaji yang bersifat berjenjang menurut kedudukan dalam hirarki;

7. Pos jabatan adalah lapangan kerja yang pokok bagi para pejabat;

8. Struktur karir dan promosi dimungkinka atas dasar senioritas dan keahlian dan pertimbangan keunggulan;

9. Pejabat sangat mungkin tidak sesuai dengan pos jabatannya maupun dengan sumbersumber yang tersedia di pos tersebut;

10.Pejabat tunduk pada sistem disiplin dan kontrol yang seragam.

Pandangan birokrasi ideal tersebut memberikan beberapa pengertian. Pertama, birokrasi merupakan suatu organisai formal yang bekerja berdasarkan aturan yang disiplin. Kedua, dalam birokrasi ternyata terdapat otoritas dan kekuasaan tertentu. Ketiga, birokrasi memiliki susunan posisi secara hirarki dan bersifat mengikat. Keempat, kenaikkan pangkat dalam birokrasi atas dasar keahlian dan kelayakan kualitas. Kelima, Pegawai merupakan staf yang berkerja secara profesionalitas dan dibayar tetap.

Dalam penjelasan umum Undang-Undang Nomor 7 tahun 2017 tentang pemilihan umum dinyatakan Pasal 1 ayat (2) Undang-Undang Dasar Negara Republik Indonesia Tahun 1945 menyatakan bahwa "Kedaulatan berada di tangan rakyat dan dilaksanakan menurut Undang-Undang Dasar". Makna dari "kedaulatan berada di tangan rakyat" yaitu bahwa rakyat memiliki kedaulatan, tanggung jawab, hak dan kewajiban untuk secara demokratis memilih pemimpin yang akan membentuk pemerintahan guna mengurus dan melayani seluruh lapisan masyarakat, serta memilih wakil rakyat untuk mengawasi jalannya pemerintahan. Perwujudan kedaulatan rakyat dilaksanakan melalui Pemilu sebagai sarana bagi rakyat untuk memilih pemimpin melalui Pemilihan Presiden dan Wakil Presiden yang dipilih dalam satu pasangan secara langsung serta memilih wakilnya yang akan menjalankan fungsi melakukan pengawasan, menyalurkan aspirasi politik rakyat, membuat undang-undang sebagai landasan bagi semua pihak di Negara Kesatuan Republik Indonesia dalam menjalankan fungsi masingmasing, serta merumuskan anggaran pendapatan dan belanja untuk membiayai pelaksanaan fungsi-fungsi tersebut.

Secara prinsipil, UndangUndang ini dibentuk dengan dasar menyederhanakan dan menyelaraskan serta menggabungkan pengaturan Pemilu yang termuat dalam tiga UndangUndang, yaitu Undang-Undang Nomor 42 Tahun 2008 tentang Pemilihan Umum Presiden dan Wakil Presiden, UndangUndang Nomor 15 Tahun 2011 tentang Penyelenggara Pemilihan Umum, dan Undang-Undang Nomor 8 Tahun 2012 tentang Pemilihan Umum Anggota Dewan Perwakilan Rakyat, Dewan Perwakilan Daerah, dan Dewan Perwakilan Rakyat Daerah. Selain itu, juga dimaksudkan untuk menjawab dinamika politik terkait pengaturan penyelenggara dan peserta Pemilu, sistem pemilihan, manajemen Pemilu, dan penegakan hukum dalam satu Undang-Undang, yaitu Undang-Undang tentang Pemilihan Umum. 
Dalam Undang-Undang ini juga diatur mengenai kelembagaan yang melaksanakan Pemilu, yakni KPU, Bawaslu, serta DKPP. Kedudukan ketiga lembaga tersebut diperkuat dan diperjelas tugas dan fungsinya serta disesuaikan dengan perkembangan kebutuhan hukum dalam Penyelenggaraan Pemilu. Penguatan kelembagaan dimaksudkan untuk dapat menciptakan Penyelenggaraan Pemilu yang lancar, sistematis, dan demokratis. Secara umum Undang-Undang ini mengatur mengenai penyelenggara Pemilu, pelaksanaan Pemilu, pelanggaran Pemilu dan sengketa Pemilu, serta tindak pidana Pemilu.

Karakteristik dasar sistem presidensial adalah keterpisahan antara eksekutif dan legislatif (executive is not dependent on legislative) dan baik presiden (kepala eksekutif) maupun anggota legislatif sama-sama dipilih langsung rakyat. Masalah bawaan itu ada tiga, yaitu : ${ }^{11}$

Pertama, dual legitimacy. Karena sama-sama dipilih rakyat maka baik presiden maupun legislatif memiliki legitimasi yang sama kuat.

Kedua, rigidity. Baik legislatif maupun presiden memiliki masa jabatan yang tetap. Kecuali karena alasan-alasan seperti kriminal atau penghianatan terhadap konstitusi, seorang presiden tidak dapat dijatuhkan ditengah jalan.

Ketiga, majoritarian tendency. Ketika seorang presiden memiliki kecenderungan mengabaikan legislatif (imperial president) atau ketika presiden merasa menghadapi legislatif yang tidak bersahabat (legislatif dikuasai oposisi atau divided government), maka dia dapat atau akan mencari celah-celah konstitusional dan politik untuk memperluas kekuasaannya. Ini dapat

11 Djayadi Hanan, Memperkuat Presidensialisme Multipartai di Indonesia: Pemilu Serentak, Sistem Pemilu, dan Sistem Kepartaian, diakses tanggal 10 September 2018, hal. 2 berujung pada makin lemahnya legislatif dan rejim politik menjadi otoritarian.

Dalam sistem presidensial multipartai, presiden yang terpilih cenderung akan tidak memiliki dukungan mayoritas di legislatif. Banyaknya partai yang ikut pemilu (termasuk partai presiden) membuat sangat sulit bagi satu partai untuk memenangkan pemilu secara mayoritas. Ini berujung pada minoritasnya dukungan presiden di legislatif, sekalipun partainya adalah partai pemenang pemilu. Dalam sistem multipartai biasanya dukungan mayoritas legislatif diperoleh melalui koalisi. Namun, karena presiden tidak tergantung pada legislatif, insentif untuk membentuk koalisi tidaklah sebesar sistem parlementer. Presiden tetap dapat membentuk pemerintahan tanpa melibatkan partai-partai di legislatif. Ini berarti dia sangat mungkin berhadapan dengan legislatif yang memusuhinya. Hasilnya adalah hubungan eksekutif--legislatif yang terus menerus tegang dan konflik yang berujung pada kebuntuan (deadlock). Dampaknya adalah pemerintahan sulit memiliki kinerja yang baik. ${ }^{12}$

Pemilu

legislatifnya menggunakan sistem proporsional, ada dua aspek utama dari sistem pemilu yang harus diperhitungkan bila ingin melakukan penyederhanaan sistem kepartaian atau tersedianya dukungan politik yang memadai bagi seorang presiden. Pertama, waktu pelaksanaan pemilu legislative dan eksekutif (presiden). Ada dua variannya di sini: pelaksanaan secara terpisah dan pelaksanaan secara serentak. Kedua, formula elektoral untuk pemilihan presiden. Juga ada dua variannya: plurality dan majority runoff. Dalam formula plurality, pemilu presiden berlangsung hanya satu putaran. Siapapun yang memperoleh suara 
terbanyak dialah yang menjadi pemenang. Dalam majority runoff seorang calon presiden harus memenangkan minimal 50 persen lebih untuk menjadi pemenang. Bila tidak terdapat pemenang, maka diadakan putaran kedua yang diikuti oleh ranking pertama dan kedua dari putaran pertama. Sistem majority runoff ini adalah sistem yang digunakan untuk pemilihan presiden di Indonesia hingga saat ini. ${ }^{13}$

Secara umum, untuk konteks Indonesia dengan mendasarkan pada varian secara empirik maupun hipotetis, terdapat setidaknya enam model pemilu serentak. $^{14}$

1. Pemilu serentak sekaligus serentak, satu kali dalam lima tahun, untuk semua posisi rakyat di tingkat nasional hingga kabupaten/kota. Pemilu ini meliputi pemilihan legislatif (DPR, DPD, DPRD Propinsi dan DPRD Kab/Kota), pemilihan presiden, serta pemilukada. Ini seringkali disebut dengan pemilihan tujuh kotak atau pemilu borongan.

2. Pemilu serentak hanya untuk seluruh jabatan legislatif (pusat dan daerah) dan kemudian disusul dengan pemilu serentak untuk jabatan eksekutif (pusat dan daerah). Dalam model clustered concurrent election ini, pemilu untuk DPR, DPD, DPRD Propinsi dan DPRD Kab/Kota dilaksanakan seperti selama ini dilakukan bersamaan sesuai waktunya, dan kemudian diikuti pemilu presiden, gubernur dan

\footnotetext{
${ }^{13}$ Ibid. Hal. 4

14 lembaga ilmu pengetahuan indonesia, draf-ringkasan eksekutif position paper pemilu nasional serentak 2019, Hal. 5-6 diakses tanggal 10 September 2018
}

bupati/walikota bulan kemudian.

beberapa

3. Pemilu serentak dengan pemilu sela berdasarkan tingkatan pemerintahan, di mana dibedakan waktunya untuk pemilu nasional dan pemilu daerah/lokal (concurrent election with mid-term election). Dalam model ini pemilu anggota DPR dan DPD dibarengkan pelaksanaannya dengan pemilu presiden. Sementara pemilu DPRD Propinsi, kabupaten/kota dibarengkan pelaksanaannya dengan pemilihan gubernur dan bupati/walikota, dua atau tiga tahun setelah pemilu nasional.

4. Pemilu serentak tingkat nasional dan tingkat lokal yang dibedakan waktunya secara interval (concurrent election with regional-based concurrent elections). Dalam model ini, pemilihan presiden dan pemilihan legislatif untuk DPR dan DPD dilakukan bersamaan waktunya. Kemudian pada tahun kedua diadakan pemilu serentak tingkat lokal untuk memilih DPRD Propinsi dan Kabupaten/Kota serta pemilihan Gubernur dan Bupati/Walikota berdasarkan pengelompokan region atau wilayah kepulauan tertentu. Misal tahun kedua khusus untuk wilayah Pulau Sumatera. Kemudian disusul tahun ketiga untuk wilayah pulau Jawa, dan tahun keempat untuk wilayah Bali dan Kalimantan, dan tahun kelima untuk wilayah sisanya. Dengan model ini maka setiap tahun masing- 
masing partai akan selalu bekerja untuk mendapatkan dukungan dari pemilih, dan pemerintah serta partai politik dapat selalu dievaluasi secara tahunan oleh pemilih.

5. Pemilu serentak tingkat nasional yang kemudian diikuti dengan pemilu serentak di masing-masing provinsi berdasarkan kesepakatan waktu atau siklus pemilu lokal di masingmasing provinsi tersebut. Dengan model concurrent election with flexible concurrent local elections ini maka pemilihan Presiden dibarengkan dengan pemilihan legislatif untuk DPR dan DPD. Kemudian setelahnya tergantung dari siklus maupun jadual pemilu lokal yang telah disepakati bersama diadakan pemilu serentak tingkat lokal untuk memilih Gubernur, Bupati, dan Walikota serta memilih anggota DPRD Provinsi dan Kabupaten/Kota di suatu provinsi, dan kemudian diikuti dengan pemilu serentak lokal yang sama di provinsi-provinsi lainnya sehingga bisa jadi dalam setahun ada beberapa pemilu serentak lokal di sejumlah provinsi.

6. Pemilu serentak untuk memilih anggota DPR, DPD, dan DPRD serta Presiden dan Wakil Presiden dan kemudian diikuti setelah selang waktu tertentu dengan pemilu eksekutif bersamaan untuk satu provinsi. Dalam pemilu ini, pemilu serentak tingkat lokal hanyalah untuk memilih Gubernur, Bupati dan Walikota secara bersamaan di suatu provinsi, dan jadualnya tergantung dari siklus pemilu lokal di masing-masing provinsi yang telah disepakati.

Pada model pertama, kedua, dan ketiga, jika tujuan pemilu serentak hanya untuk sekedar penghematan biaya memang terjawab. Namun penyelenggaraan pemilu menjadi semakin rumit, konfigurasi politik menjadi tidak menentu, bahkan bisa jadi tidak muncul political blocking secara jelas dan dapat menyuburkan politik transaksional karena kebutuhan terhadap dukungan elektoral untuk memenangkan pemilu. Sementara pelaksanaan pemilu serentak pada model ketiga, keempat, dan kelima diyakini membuat sistem pemilihan lebih sederhana. Dengan dilaksanakannya pemilu untuk anggota DPR dan pemilihan Presiden secara bersamaan maka kecenderungannya ialah hanya terdapat dua blok besar koalisi partai politik, dimana keduanya mencalonkan pasangan capres cawapres masing-masing karena kemungkinan mengarah pada dua putaran atau hanya dua kandidat utama sangat besar.

Pemerintahan presidensial akan berlangsung efektif apabila tidak disertai sistem kepartaian pluralisme ekstrim melainkan ditopang oleh sistem kepartaian pluralism sederhana, atau sistem kepartaian pluralisme moderat untuk konteks Indonesia. Apabila desain sistem pemilihan umum tersebut berhasil menyederhanakan jumlah partai politik, maka sistem kepartaian yang akan muncul adalah pluralism moderat. Sistem kepartaian pluralism moderat ditandai oleh dua karakteristik: jumlah kemungkinan pihak yang dapat membentuk pemerintahan terdiri atas dua kutub (dua koalisi), dan jarak ideologi antar kutub partai tidak terlalu jauh sehingga keduanya masih mampu mencapai kesepakatan. ${ }^{15}$

${ }^{15}$ Ibid. Hal. 62 
Dalam penjelasan umum Undang-Undang Nomor 7 tahun 2017 tentang Pemilihan Umum, menyatakan sesuai dengan ketentuan Pasal 22E Undang-Undang Dasar Negara Republik Indonesia Tahun 1945, Pemilu untuk memilih Presiden dan Wakil Presiden, anggota DPR, anggota DPD, serta anggota DPRD diselenggarakan berlandaskan asas langsung, umum, bebas, rahasia, jujur, dan adil setiap lima tahun sekali. Penyelenggaraan Pemilu Presiden dan Wakil Presiden dilaksanakan dengan tujuan untuk memilih Presiden dan Wakil Presiden yang memperoleh dukungan kuat dan rakyat sehingga mampu menjalankan fungsi kekuasaan pemerintahan negara dalam rangka tercapainya tujuan nasional sebagaimana diamanatkan dalam Pembukaan Undang-Undang Dasar Negara Republik Indonesia Tahun 1945. Di samping itu, pengaturan terhadap Pemilu Presiden dan Wakil Presiden dalam Undang-Undang ini juga dimaksudkan untuk menegaskan sistem presidensiil yang kuat dan efektif, di mana Presiden dan Wakil Presiden terpilih tidak hanya memperoleh legitimasi yang kuat dari rakyat, namun dalam rangka mewujudkan efektivitas pemerintahan juga diperlukan basis dukungan dari DPR.

DPD, $\begin{array}{rr}\text { Pemilu anggota DPR, anggota } \\ \text { dan angota }\end{array}$ diselenggarakan dengan menjamin prinsip keterwakilan, yang artinya setiap Warga Negara Indonesia dijamin memiliki wakil yang duduk di lembaga perwakilan yang akan menyuarakan aspirasi rakyat di setiap tingkatan pemerintahan, dari pusat hingga ke daerah. Pemilu yang terselenggara secara langsung, umum, bebas, rahasia, jujur, dan adil merupakan syarat mutlak untuk mewujudkan wakil rakyat yang berkualitas, dapat dipercaya, dan dapat menjalankan fungsi kelembagaan legislatif secara optimal. Penyelenggaraan Pemilu yang baik dan berkualitas akan meningkatkan derajat kompetisi yang sehat, partisipatif, dan keterwakilan yang makin kuat dan dapat dipertanggungjawabkan.

Memperkuat sistem presidensial sangat terkait dengan tersedianya dukungan politik yang memadai di lembaga legislatif bagi seorang presiden. Dukungan yang memadai itu dimaknai secara operasional sebagai dukungan mayoritas (50 persen lebih) atau hampir mayoritas (mendekati 50) persen. Bila seorang presiden memiliki dukungan kurang dari ambang batas tersebut, maka sulit bagi seorang presiden untuk menjalankan agenda-agenda pemerintahannya. Akibat selanjutnya adalah kurang atau tidak berfungsinya sistem presidensial, atau lebih buruk lagi bisa berujung pada kegagalan pemerintahan. ${ }^{16}$

Dengan asumsi bahwa pemilu legislatif dilaksanakan dengan sistem proporsional dan besaran dapil (district magnitude) normal menunjukkan bahwa kombinasi yang paling mungkin memperkuat sistem presidensiil adalah kombinasi pemilihan presiden dengan sistem plurality dan waktu pelaksanaannya serentak dengan pemilihan legislatif. Kombinasi lain semuanya cenderung menghasilkan sistem multipartai yang tinggi. ${ }^{17}$ Atas dasar temuan seperti ini, Jones dan banyak peneliti lain, terutama di Amerika Latin menyarankan agar sistem pemilu legislatif dan eksekutif dalam sistem presidensial multipartai haruslah mengkombinasikan waktu pelaksanaan yang serentak, sistem Proportional dalam pemilu legislatif, dan sistem plurality dalam menentukan pemenang pemilu presidennya.

Sistem plurality sendiri sebetulnya cenderung menghasilkan sedikit kandidat presiden. Ketika pemilu presiden para pendukung kandidat dalam

\footnotetext{
${ }^{16}$ Djayadi Hanan, Op. Cit. Hal.3

${ }^{17}$ Ibid. Hal. 5
} 
sistem ini cenderung mengabaikan para kandidat yang tidak kompetitif (non-viable) supaya mereka dapat fokus pada dua kandidat teratas. Hal ini mendorong proses koalisi antar partai sejak awal karena hanya ada satu putaran pemilihan. Partai yang mestinya mengajukan calon sendiri namun calonnya kurang kompetitif cenderung akan mendrop calonnya dan mengendorse satu di antara dua calon paling kompetitif dengan harapan akan mendapatkan konsesi politik pasca pemilu presiden. Namun, bila dilaksanakan terpisah dengan pemilu legislatif, maka partai-partai dalam pemilu legislatif belum perlu memikirkan pengaruh pemilu presiden tersebut. Dampak "reduktif" dari sistem plurality menjadi tidak berpengaruh terhadap penyederhanaan partai di legislatif, dengan asumsi pemilu legislatif dilaksanakan dengan sistem proporsional.

Mekanisme plurality ini berpengaruh terhadap partai-partai ketika dilaksanakan serentak dengan pemilu legislatif. Partai-partai cenderung akan mencalonkan salah satu dari dua kandidat paling kompetitif, dan berujung pada mengumpulnya dukungan partai-partai legislatif pada dua kandidat tersebut. Ketika salah satu dari kandidat itu memenangkan pemilu presiden, maka dukungan terhadap presiden tersebut di legislatif cenderung akan mayoritas atau mendekati mayoritas. Dengan demikian gabungan sistem pemilu presiden plurality yang dilaksanakan serentak dengan pemilu legislatif adalah yang paling mungkin membantu penguatan sistem presidensial multipartai.

Saat ini Indonesia menganut sistem pemilu legislatif proporsional, dengan jumlah kursi perdapil (district magnitude) yang rentangnya cukup besar, antara tiga hingga sepuluh kursi. Sistem pemilu presiden adalah MRO, dengan tambahan persyaratan persebaran dukungan yang merata secara nasional bila seorang kandidat menang di putaran pertama.

Berdasarkan temuan-temuan utama yang telah dipaparkan di atas, bila pemilu tahun 2019 nanti dilaksanakan serentak maka skenario yang mungkin terjadi adalah pertama, setiap partai peserta pemilu atau sebagian besarnya akan mengajukan capres-cawapres sendiri di putaran pertama yang berbarengan dengan pemilu legislatif. Keadaannya kemungkinan tak akan berbeda dengan pemilu tahun 2004, 2009, dan 2014. Bila ada kandidat sangat populer bisa saja ia menarik suara lebih banyak kepada partainya. Pengalaman tahun 2014 menunjukkan bahwa sekalipun pemilu presiden terpisah, calon-calon presiden populer sudah bermunculan sejak pemilu legislatif. Namun dampaknya tidak terlalu terlihat terhadap perubahan jumlah partai. Sistem kepartaian legislatif kita tetap multipartai yang tinggi (fragmented). Jadi pelaksanaan pemilu serentak dengan formula MRO untuk presiden kemungkinan tidak akan mengurangi jumlah partai di DPR.

Meskipun menurut temuan di atas sulit terjadi, bisa ada kemungkinan kedua. Bila ada calon yang sangat populer atau kompetitif (tahun 2019 nanti kemungkinan ada kandidat incumbent), bisa saja banyak partai akan mendukung calon yang populer tersebut. Maka partai-partai yang kandidatnya sama akan dipilih karena alasan lain, bukan karena semata kandidat presidennya. Tapi ini baru spekulasi, masih harus dilakukan penelitian tentang apakah seorang kandidat presiden yang populer dapat memberikan pengaruh yang sama besar kepada setiap partai pendukungnya dalam pemilu legislatif yang serentak dengan pemilu eksekutif. Tapi skenario inipun mungkin tetap akan berakhir dengan tetap terfragmentasinya partai di DPR, karena partai-partai yang mendukung kandidat yang dianggap populer tersebut tetap mendapatkan 
tempat di DPR sekalipun jumlah kursinya kecil.

Penyelenggaraan serentak pemilu ini dilaksanakan dengan tujuan untuk memilih Presiden dan Wakil Presiden yang memperoleh dukungan kuat dan rakyat sehingga mampu menjalankan fungsi kekuasaan pemerintahan negara dalam rangka tercapainya tujuan negara diamanatkan dalam Pembukaan UndangUndang Dasar Negara Republik Indonesia Tahun 1945 dan juga dimaksudkan untuk menegaskan sistem presidensiil yang kuat dan efektif, di mana Presiden dan Wakil Presiden terpilih tidak hanya memperoleh legitimasi yang kuat dari rakyat, namun dalam rangka mewujudkan efektivitas pemerintahan juga diperlukan basis dukungan dari DPR. Sistem plurality sendiri sebetulnya cenderung menghasilkan sedikit kandidat presiden. Ketika pemilu presiden para pendukung kandidat dalam sistem ini cenderung mengabaikan para kandidat yang tidak kompetitif (non-viable) supaya mereka dapat fokus pada dua kandidat teratas. Hal ini mendorong proses koalisi antar partai sejak awal karena hanya ada satu putaran pemilihan. Partai yang mestinya mengajukan calon sendiri namun calonnya kurang kompetitif cenderung akan mendrop calonnya dan mengendorse satu di antara dua calon paling kompetitif dengan harapan akan mendapatkan konsesi politik pasca pemilu presiden. Namun, bila dilaksanakan terpisah dengan pemilu legislatif, maka partai-partai dalam pemilu legislatif belum perlu memikirkan pengaruh pemilu presiden tersebut. Dampak "reduktif" dari sistem plurality menjadi tidak berpengaruh terhadap penyederhanaan partai di legislatif, dengan asumsi pemilu legislatif dilaksanakan dengan sistem proporsional.

Mekanisme plurality ini berpengaruh terhadap partai-partai ketika dilaksanakan serentak dengan pemilu legislatif. Partai-partai cenderung akan mencalonkan salah satu dari dua kandidat paling kompetitif, dan berujung pada mengumpulnya dukungan partai-partai legislatif pada dua kandidat tersebut. Ketika salah satu dari kandidat itu memenangkan pemilu presiden, maka dukungan terhadap presiden tersebut di legislatif cenderung akan mayoritas atau mendekati mayoritas. Dengan demikian gabungan sistem pemilu presiden plurality yang dilaksanakan serentak dengan pemilu legislatif adalah yang paling mungkin membantu penguatan sistem presidensial multipartai.

Penyelenggaraan serentak pemilu ini dilaksanakan dengan tujuan untuk memilih Presiden dan Wakil Presiden yang memperoleh dukungan kuat dan rakyat sehingga mampu menjalankan fungsi kekuasaan pemerintahan negara dalam rangka tercapainya tujuan negara diamanatkan dalam Pembukaan UndangUndang Dasar Negara Republik Indonesia Tahun 1945 dan juga dimaksudkan untuk menegaskan sistem presidensiil yang kuat dan efektif, di mana Presiden dan Wakil Presiden terpilih tidak hanya memperoleh legitimasi yang kuat dari rakyat, namun dalam rangka mewujudkan efektivitas pemerintahan juga diperlukan basis dukungan dari DPR. Saat ini Indonesia menganut sistem pemilu legislatif proporsional, dengan jumlah kursi perdapil (district magnitude) yang rentangnya cukup besar, antara tiga hingga sepuluh kursi. Sistem pemilu presiden adalah MRO, dengan tambahan persyaratan persebaran dukungan yang merata secara nasional bila seorang kandidat menang di putaran pertama.

\section{PENUTUP}

Penyelenggaraan pemilu serentak dengan Sistem plurality sendiri sebetulnya cenderung menghasilkan sedikit kandidat presiden. Ketika pemilu presiden para pendukung kandidat dalam sistem ini cenderung mengabaikan para kandidat yang tidak kompetitif 
(non-viable) supaya mereka dapat fokus pada dua kandidat teratas. Hal ini mendorong proses koalisi antar partai sejak awal karena hanya ada satu putaran pemilihan. Partai yang mestinya mengajukan calon sendiri namun calonnya kurang kompetitif cenderung akan mendrop calonnya dan mengendorse satu di antara dua calon paling kompetitif dengan harapan akan mendapatkan konsesi politik pasca pemilu presiden. Sistem plurality bila dilaksanakan terpisah dengan pemilu legislatif, maka partai-partai dalam pemilu legislatif belum perlu memikirkan pengaruh pemilu presiden tersebut. Mekanisme plurality ini berpengaruh terhadap partai-partai ketika dilaksanakan serentak dengan pemilu legislatif. Partai-partai cenderung akan mencalonkan salah satu dari dua kandidat paling kompetitif, dan berujung pada mengumpulnya dukungan partai-partai legislatif pada dua kandidat tersebut. Ketika salah satu dari kandidat itu memenangkan pemilu presiden, maka dukungan terhadap presiden tersebut di legislatif cenderung akan mayoritas atau mendekati mayoritas. Gabungan sistem pemilu presiden plurality yang dilaksanakan serentak dengan pemilu legislatif adalah yang paling mungkin membantu penguatan sistem presidensial multipartai. Dengan demikian penyelenggaraan pemilu serentak akan memkuat sistem presidensiil di mana Presiden dan Wakil Presiden terpilih memperoleh legitimasi yang kuat dari rakyat, dalam rangka mewujudkan efektivitas pemerintahan dan juga basis dukungan dari DPR.

\section{DAFTAR PUSTAKA}

Abdul Kadir Muhammad, 2004, Hukum Dan Penelitian Hukum, PT. Citra Aditya Bakti, Bandung,

Azhari. 2011. Mereformasi Birokrasi Rakyat Indonesia. Yogyakarta: Penerbit Pustaka Belajar
Jimly Asshiddiqie, Format Kelembagaan Negara dan Pregeseran Kekuasaan Dalam UUD 1945, Yogyakarta: FH UII Press, 2005, Cet. Kedua

Djayadi Hanan, Memperkuat Presidensialisme Multipartai di Indonesia: Pemilu Serentak, Sistem Pemilu, dan Sistem Kepartaian, diakses tanggal 10 September 2018

Khairul Fahmi, 2011. Pemilihan Umum dan Kedaulatan Rakyat. Rajawali Pers Jakarta.

Hamka. 2014. Ketidaknetralan Birokrasi Indonesia. Jakarta: PT Elex Media Komputindo

Rahmat Hollyson, 2014. Pilkada (Penuh Euforia, Miskin Makna). Jakarta: Pernerbit Bestari

lembaga ilmu pengetahuan indonesia, draf-ringkasan eksekutif position paper pemilu nasional serentak 2019, hal. 5-6 diakses tanggal 10 September 2018

Jhonny Ibrahim, 2006, Teori dan Metodologi Penelitian Hukum Normatif, Bayumedia, Malang,

Delly Mustafa2014. Birokrasi Pemerintahan. Bandung: Penerbit Alfabeta

Ronny Hanitijo Soemitro, 1988, Metodologi Penelitian Hukum dan Jurimetri, Ghalia Indonesia.

Peter Mahmud Marzuki, 2008, Penelitian Hukum, Kencana Prenada Media Group, Jakarta

Sanapiah Faisal, 1990, Penelitian Kualitatif : Dasar-Dasar dan Aplikasi, YA 3, Malang,

Sugiyono. 2012. Metode Penelitian Kuantitatif Kualitatif dan R\&D. Bandung: Penerbit Alfabeta.

Titik Triwulan Tutik, Konstruksi Hukum Tata Negara Indonesia Pasca Amandemen UUD 1945 , 
Barhamudin, Pemilhan Umum Serentak Dapat Memperkuat Sistem Presidensial Halaman 227-240

Jakarta: Kencana, 2011, Cet. Kedua,

Thohah Miftah. 2003. Birokrasi dan Politik Indonesia. Jakarta: PT Grafindo Persada

Thohah Miftah. 2010. Kepemimpinan dan Manajeman. Jakarta: PT Grafindo Persada 